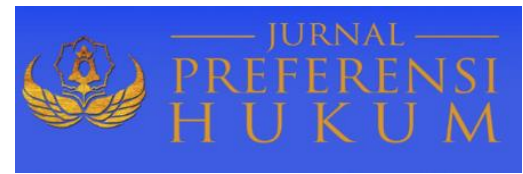

Jurnal Preferensi Hukum | ISSN: XXXX | E-ISSN: XXXX

Vol. 1 No. 1 - Juli 2020 hal. 228-233| Available online at https://www.ejournal.warmadewa.ac.id/index.php/juprehum

\title{
KEDUDUKAN HUKUM PERJANJIAN KREDIT DALAM HAL OBJEK JAMINAN FIDUSIA MUSNAH
}

\author{
I Gusti Agung Mas Cahyani Dewi, Anak Agung Sagung Laksmi Dewi, Ni Made Puspasutari Ujianti \\ Fakultas Hukum Universitas Warmadewa, Denpasar, Bali-Indonesia
}

\begin{abstract}
Abstrak
Aktivitas pemberian kredit dapat dilakukan oleh siapa saja yang memiliki kemampuan untuk memulai perjanjian utang piutang antara pemberi utang/kreditur dan penerima pinjaman/debitur, hal ini diatur dalam pasal 8 Undang Undang Perbankan. Penelitian inibertujuan untuk menganalisis kedudukan hukum dalam perjanjian kre dit jika objek jaminan fidusia musnah, dan menganalis is upaya penyelesaian sengketa akibat musnahnya objek jaminan fidusia. Metode yang digunakan adalah metode empiris dengan pendekatan sosiologi hukum. Hasil penelitian menunjukan bahwa kedudukan hukum perjanjian kredit jika objek jaminan fidusia musnah baik dalam hal benda yang menjadi objek telah diasuransikan maupun belum diasuransikan oleh pemilik benda. Perjanjian kreditnya tetap ada dan debitur tetap bertanggung jawab atas pelunasan atas utangnya. Den gan situasi tersebut maka pihak kreditur akan berubah menjadi kreditur konkuren. Selanjutnya, dalam menyelesaikan sengketa musnahnya objek jaminan fidusia terdapat dua cara yaitu, jika benda yang dijadikan objek jaminan fidusia oleh debitur dalam suatu perjanjian kredit telah diasuransikan maka pihak kreditur bisa mengklaim asuransi atas benda yang dijaminkan tersebut. Sedangkan jika benda yang dijadikan jaminan belum diasuransikan dalam hal ini kreditur telah mengeluarkan kredit dan sedang mengurus asuransi benda tersebut, terjadi peristiwa yang tidak diinginkan oleh pihak debitur maupun kreditur yaitu musnahnya benda yang dijadikan jaminan. Maka debitur tetap harus ertanggung jawab dengan mengganti benda yang dijaminkan dengan benda baru yang dimiliki pihak debitur dan nilai jualnya sama dengan kredit yang telah dikeluarkan oleh pihak kreditur.
\end{abstract}

Kata Kunci: Perjanjian Kredit; Jaminan Fidusia; Musnahnya Objek Jaminan Fidusia

\begin{abstract}
Crediting activities can be carried out by anyone who has the ability to initiate a loan agreement between the creditor/creditor and the recipient of the loan/debtor, this is regulated in article 8 of the Banking Act. This study aims to analyze the legal position in the creditagreement if the fiduciary collateral object is destroyed, and analyze efforts to resolve disputes due to the destruction of the fiduciary collateral object. The method used is an empirical method with the approach of legal sociology. The results showed that the legal position of the credit agreement if the fiduciary collateral object was destroyed either in the case that the object became the object had been insured or not insured by the owner of the object. The credit agreement remains and the debtor remains responsible for paying off the debt. With this situation, the creditor will turn into a concurrent creditor. Furthermore, in resolving disputes the destruction of fiduciary collateral objects, there are two ways, namely, if the object used as fiduciary collateral object by the debtor in a credit agreement is insured, the creditor can claim insurance for the collateralized object. Whereas if the object which is used as collateral has not been insured in this case the creditor has issued a credit and is taking care of the object's insurance, an undesirable event occurs by the debtor and the creditor, namely the destruction of the object used as collateral. Then the debtor must be held responsible by replacing the items pledged with new objects owned by the debtor and the selling price is the same as the credit issued by the creditor.
\end{abstract}

Keywords: Credit Agreement; Fiduciary Guarantee; the Destruction of Fiduciary Objects

\section{PENDAHULUAN}

Pembangunan Hukum di Negara Republik Indonesia difokuskan pada pengembangan peraturan perundang-undangan untuk menunjang pembangunan ekonomi. Disamping itu, pembangunan di bidang hukum harus mampu mengikuti perkembangan masyarakat yang saat ini sedang berkembang kearah 
modernisasi. Semua kebutuhan dan pengaturan kehidupan masyarakat berdasarkan tingkat kemampuannya harus ditampung dalam pembangunan hukum.

Dalam menunjang dunia usaha tidak terlepas dari permodalan Lembaga Perbankan memiliki peran dalam pertumbuhan ekenomi di Negara Republik Indonesia. Dalam pertumbuhan ekonomi, bank memiliki peran untuk membantu para nasabah atau debitur yang memerlukan danadengan cara pemberian kredit yang berfungsi untuk membantu meningkatkan produktivitas dalam memajukan pembangunan. Dalam hal ini lembaga perbankan bertindak sebagai pemberi dana atau biasanya disebut dengan kreditur.

Pemberian kredit terhadap debitur dilakukan dalam dunia perbankan maupun lembaga pembiayaan melalui suatu perjanjian yaitu perjanjian pokok yang biasanya diikuti dengan perjanjian tambahan dari perjanjian pokok. Pada umumnya perjanjian pokok berupa perjanjian utang piutang, perjanjian pinjam meminjam, perjanjian kredit atau perjanjian lainnya yang mengakibatkan timbulnya hubungan hukum utang-piutang antara kreditur dengan debitur. Dalam perjanjian utang piutang diperjanjikan salah satunya antara debitur dengan kreditur bahwa pinjaman tersebut dibebani dengan suatu jaminan, yang nantinya akan diikuti dengan pengikatan jaminan yang dapat berupa pengikatan jaminan kebendaan atau jaminan perseorangan.

Pemberian kredit dapat dilakukan oleh siapa saja yang memiliki kemampuan untuk memulai perjanjian utang piutang antara pemberi utang/kreditur dan penerima pinjaman/debitur, hal ini diatur dalam pasal 8 Undang-Undang Perbankan. Pemberian kredit yang dilakukan oleh lembaga perbankan atau lembaga pembiayaan tentu ada resikonya, untuk meminimalisir resiko yang timbul maka perjanjian kredit harus disertakan suatu lembaga jaminan yang berfungsi untuk memberikan keamaan pemberi kredit. Jika debitur melakukan wanprestasi maka kreditur mempunyai hak untuk menuntut piutangnya terhadap kekayaan debitur yang dipakai suatu jaminan dalam perjanjian kredit. Hal ini adalah wujud dari prinsip kehati-hatian lembaga perbankan yang telah diatur dalam Undang-Undang Republik Indonesia Nomor 10 Tahun 1998 perubahan atas Undang-Undang Nomor 7 Tahun 1992 selanjutnya disebut dengan Undang-Undang Perbankan.

Lembaga jaminan yang saat ini sering diterapkan dalam perjanjian kredit salah satunya adalah jaminan fidusia, lembaga ini dapat digunakan jika objek jaminanannya adalah benda bergerak. Le mbaga jaminan fidusia merupakan suatu perjanjian accessoir dari perjanjian utang piutang (kredit) merupakan hasil perkembangan dari lembaga jaminan gadai. Jaminan fidusia telah digunakan di Indonesia sejak zaman penjajahan Belanda sebagai suatu bentuk jaminan yang lahir dari yurisprudensi. Isi janji yang dibuat oleh debitur dengan krediturnya adalah debitur akan mengalihkan kepemilikan atas suatu benda sebagai jaminan utangnya dengan kesepakatan bahwa debitur tetap akan menguasai secara fisik benda tersebut dan kreditur akan mengalihkan kembali kepemilikan tersebut kepada debitur jika utangnya sudah dibayar lunas. Dengan tetap menguasai benda tersebut, pemberi fidusia dapat menggunakan benda dimaksudkan dalam menjalankan usahanya (F. G. Tumbuan, 2000). Hal ini juga diterangkan oleh peneliti sebelumnya dari (Hariyani, 2016) bahwa hak Atas Kekayaan Intelektual (HAKI) khususnya Hak Cipta sudah dilegalkan sebagai obyek jaminan utang melalui skema Fidusia berdasarkan Pasal 16 UU No. 28 Tahun 2014. HAKI yang berwujud nyata (material) dan bersifat benda (tangible) dapat diikat dengan jaminan Gadai dan/atau Fidusia. Sedangkan HAKI yang tidak nyata (immaterial) atau tak-benda (intangible) hanya bisa diikat dengan jaminan Fidusia.

Penyerahan hak milik yang tanpa disertai dengan penyerahan fisik ini dalam prakteknya sering terjadi hal-hal yang tidak diinginkan oleh para pihak, seperti objek jaminan yang diikat dengan jaminan fidusia ternyata musnah. Hal ini dapat merugikan masing-masing pihak yang terlibat dalam perjanjian kredit. Jika mengkaji pada pernyataan musnahnya benda yang menjadi objek jaminan fidusia ini, terjadi ketidakjelasan mengenai pengaturan mengenai indikator musnahnya objek jaminan fidusia dalam perjanjian kredit.

Terkait dengan kajian penelitian ini, berikut ini adalah uraian dari penelitian yang dilakukan sebelumnya. Pertama, (Putriyanti, 2017) mengkaji tentang status hukum jaminan credit bank dalam jaminan hukum Indonesia, menyatakan bahwa sistem jaminan hukum di Indonesia sudah tidak murni lagi menganut sistem tertutup, tetapi sudah mulai bergeser menjadi sistem terbuka. Kedua, (Yasir, 2016) menyatakan dalam penelitiannya bahwa pidana dalam Jaminan Fidusia dapat dijatuhkan kepada orang yang dengan sengaja memalsukan, mengubah, menghilangkan atau dengan cara apapun memberikan keterangan secara menyesatkan, yang jika hal tersebut diketahui oleh salah satu pihak tidak melahirkan jaminan Fidusia. Selanjutnya, (Jayanti, 2018) mengatakan bahwa dengan membuat jaminan fidusia 
yang mengikat akta notaris akan mampu memberikan kepastian hukum baik debitur maupun kreditur, sehingga mereka mendapat sebuah kepastian tentang apa yang mereka harapkan dalam kondisi tertentu. Terakhir, (K, 2017) menyatakan bahwa aspek-aspek hukum objek tidak bergerak seperti fidusia objek dapat dikategorikan ke dalam 3 (tiga) periode, yaitu periode sebelum hukum 41996 pada hipotek, periode setelah diberlakukannya undang-undang-undang No. 4 tahun 1996 pada hipotek, dan periode setelah undang-undang No. 42 tahun 1999 tentang fidusia. Ketentuan mengenai objek tak bergerak mengakomodasi kredit kebutuhan untuk membangun pemilik tanpa hak tanah dimana bangunan ini memiliki nilai ekonomis yang tinggi sesuai dengan prinsip horisontal pemisahan. Berdasarkan penjelasan di atas, maka penelitian baru ini bertujuan untuk menganalisis kedudukan hukum dalam perjanjian kredit jika objek jaminan fidusia musnah, dan menganalisis upaya penyelesaian sengketa akibat musnahnya objek jaminan fidusia.

\section{METODE PENELITIAN}

Penelitian ini didesain dengan menggunakan metode empiris dengan pendekatan sosiologi hukum. Selain itu, pendekatan konseptual juga diterapkan dalam penelitian ini yaitu dengan menganalisis bukubuku literatur yang berkaitan dengan penelitian ini. Adapun sumber data yang digunakan dalam penelitian ini yaitu sumber data primer yang diperoleh melalui hasil wawancara langsung ke pihak yang terkait yaitu pihak BPR Bumi Prima Dana dan pihak Koperasi Bina Karya Utama, Selain itu UndangUndang Nomor 42 Tahun 1992 tentang jaminan fidusia. Kemudian, sumber data sekunder juga digunakan dalam penelitian ini. Data sekunder diperoleh dengan cara membaca jurnal, membuat ringkasan dan kemudian dianalisis dengan menggunakan teknik deskripsi.

\section{HASIL DAN PEMBAHASAN}

\section{Kedudukan Hukum Perjanjian Kredit Jika Objek Jaminan Fidusia Musnah}

Perjanjian adalah suatu peristiwa dimana seseorang berjanji untuk mengikatkan diri kepada orang lain, dimana perjanjian tersebut berisi janji-janji yang sebelumnya telah disetujui atau disepakati oleh para pihak yang terlibat, yaitu berupa hak dan kewajiban yang melekat pada para pihak yang membuatnya dalam bentuk tertulis maupun lisan. Hal yang terpenting yaitu sahnya suatu perjanjian, jika perjanjian dinyatakan sah maka perjanjian tersebut dapat dilaksanakan oleh kedua belah pihak, tetapi jika suatu perjanjian dikatakan tidak sah maka perjanjian tersebut dinyatakan batal demi hukum. Suatu perjanjian dikatakan sah apabila memenuhi syarat-syarat yang dimaksud pada Pasal 1320 KUHPer, yang menyebutkan bahwa:

1. Kesepakatan antara kedua belah pihak.

2. Kecakapan untuk membuat perjanjian.

3. Sesuatu hal tertentu.

4. Sebab yang halal.

Melaksanakan suatu perjanjian terdapat objek dan subjek perjanjian. Adapun yang dimaksud dengan objek dalam suatu perjanjian adalah prestasi, prestasi ini harus dilaksanakan atau dipenuhi oleh pihak-pihak yang terlibat di dalam suatu perjanjian. Dalam hukum perjanjian yang dapat menjadi subjek hukumnya adalah individu/ pribadi dan badan hukum. Salah satu contoh dari bentuk perjanjian yaitu perjanjian kredit. Kredit berasal dari kata creditus yang berarti kepercayaan (Munari Fuady, 1996). Kegiatan pemberian kredit merupakan kegiatan yang sangat konvensional daru suatu bank, bahkan kegiatan Lembaga perbankan secara tradisional berfungsi untuk menghimpun dana-dana dari masyarakat dan menyarulkan dana tersebut kepada masyarakat. Dalam membuat perjanjian kredit tentu memiliki dasar-dasar hukum yang dipakai oleh Lembaga perbankan. Adapun dasar-dasar hukum tersebut, yaitu:

1. Perjanjian diantara para pihak yang terlibat.

2. Undang-Undang sebagai dasar hukum.

3. Peraturan pelaksaan sebagai dasar hukum.

4. Yurisprudensi sebagai dasar hukum.

5. Kebiasaan perbankan sebagai dasar huku.

6. Peraturan

Dalam praktek perkreditan, untuk memberikan rasa aman bagi kepentingan bank yang bertindak sebagai kreditur maka akan meminta jaminan kepada debitur. Jaminan tersebut berfungsi untuk meyakinkan pihak bank selaku kreditur bahwa debitur akan mengembalikan utang atau pinjamannya 
tepat waktu sesuai dengan kesepakatan bersama. Dengan menggunakan benda bergerak dalam suatu jaminan tentu akan ada beberapa resiko yang timbul. Salah satunya yaitu benda yang menjadi objek jaminan fidusia dapat musnah atau hilang yang tentu saja mengakibatkan benda bergerak tersebut tidak dapat diperjualbelikan. Hal tersebut terjadi akibat benda bergerak yang dijaminkan musnah karena bencana alam, seperti banjir, gempa bumi, kecelakaan, atau kebakaran yang dalam hal ini terjadi karena diluar kehendak pemilik benda. Apabila dalam suatu perjanjian kredit antara pihak kreditur dengan debitur terjadi suatu sengketa musnahnya benda yang dijaminkan dalam hal ini adalah jaminan fidusia maka perjanjian kredit yang telah disepakati tidak hapus dan tidak merubah kedudukan debitur mengingat benda yang dijaminkan telah musnah tetapi perjanjian pokoknya dalam hal ini perjanjian kredit tetap berlaku, yang berubah hanya kedudukan kreditur menjadit kreditur konkuren. Maka dari itu pihak debitur tetap bertanggung jawab atas pinjaman yang telah dikeluarkan oleh pihak kreditur.

Dalam suatu perjanjian kredit jika debitur menjaminkan suatu benda yang bisa disebut dengan jaminan fidusia maka benda tersebut harus diasuransikan terlebih dahulu sebelum pihak kreditur mengeluarkan kredit. Hal ini dilakukan untuk meminimalis ir terjadinya objek jaminan yang musnah mengingat benda yang dijadikan objek jaminan tetap dalam penguasaan pihak debitur, jika hal ini terjadi maka pihak kreditur dapat mengklaim asuransi atas benda yang dijaminkan tersebut dan menggunakan hasil klaim tersebut untuk melunasi hutang atau pinjaman dari pihak debitur.

\section{Penyelesaian Sengketa Akibat Musnahnya Objek Jaminan Fidusia}

Fidusia berasal dari kata fides yang berarti kepercayaan atas penyerahan hak milik suatu benda sebagai pelunasan hutang terhadap kreditur. Dengan adanya penyerahan hak kepemilikan atas kebendaan fidusia, bukan berarti kreditur sebagai penerima benda fidusia akan menjadi pemilik kebendaan yang dijaminkan dengan fidusia. Dengan kata lain kreditur bisa menjual kebendaan fidusia apabila debitur tidak melunasi utangnya atau debitur wanprestasi, sedangkan bila debitur mampu untuk melunasi utangnya tepat waktu maka kebendaan fidusia akan diserahkan kembali kepada debitur.

Untuk menjamin kepastian hukum dan memberikan perlindungan hukum bagi pihak yang berkepentingan maka perlu dibuat atau diadakan Lembaga jaminan fidusia. Jaminan fidusia merupakan Lembaga hak jaminan yang bersifat kebendaan yang memberikan kedudukan yang diutamakan kepada penerima fidusia terhadap kreditur lainnya. Adanya kewajiban untuk menyerahkan sesuatu membuktikan bahwa perjanjian fidusia bersifat zakelijk yang berarti hak kebendaan, dan hak ini dapat dipertahakan terhadap siapapun dan dimanapun juga (Satrio, 2005).

Jaminan fidusia diberikan sebagai agunan untuk pelunasan atas utang tertentu yang dilakukan oleh debitur kepada kreditur. Oleh karena itu jaminan fidusia merupakan perjanjian tambahan yang didasarkan pada suatu perjanjian utang-piutang atau perjanjian lain. Ada atau tidaknya jaminan fidusia tergantung pada ada atau tidaknya suatu piutang yang dijaminkan pelunasannya dengan jaminan fidusia. Dalam menggunakan jaminan fidusia harus dilakukan pembebanan jaminan fidusia terlebih dahulu dalam bentuk akta oleh notaris. Akta notaris adalah akta autentik yang mempunyai kekuatan pembuktian paling sempurna, oleh karena itu pembebanan benda dengan Jaminan Fidusia dituangkan dalam akta notaris yang merupakan Akta Jaminan Fidusia.Hal itu dikarenakan objek jaminan fidusia pada umumnya merupakan barang bergerak yang tidak terdaftar, sudah sepatutnya bentuk akta yang digunakan adalah akta autentik, karena akta autentik dianggap paling dapat menjamin kepastian hukum menyangkut dengan objek jaminan fidusia (Tumbuan, 2000).

Yang wajib didaftarkan oleh penerima fidusia dalam hal ini kreditur adalah benda yang sudah dibebani dengan jaminan fidusia. Dalam hal ini benda yang berada di dalam negeri maupun benda yang berada di luar negeri. Permohonan pendaftaranfidusia ini dilakukan sendiri oleh penerima fidusia dalam hal ini kreditur, kuasa maupun wakilnya dengan melampirkan pernyataan pendaftaran jaminan fidusia. Pendaftaran ini dilaksanakan di Kantor Pendaftaran Fidusia yang wilayah kerjanya merupakan tempat tinggal atau tempat kedudukan dari pemberi fidusia yang bersangkutan. Dengan adanya pendaftaran jaminan fidusia ini juga memberikan perlindungan bagi pihak kreditur jika objek jaminan fidusia yang penguasaannya tetap berada pada tangan debitur bisa saja mengalami kemusnahan baik karena bencana alam ataupun kelalaian dari pihak debitur.

Hapusnya jaminan fidusia akibat musnahnya benda yang menjadi objek jaminan fidusia merupakan suatu hal yang wajar karena tidak ada manfaatnya lagi jika dipertahankan mengingat benda yang menjadi objek jaminan fidusia sudah tidak ada (Munir Fuady, 2000). Jika hal ini terjadi pihak kreditur akan mengecek terlebih dahulu kebenaran tersebut dan jika benar objek yang dijaminkan 
mengalami kemusnahan maka pihak kreditur bisa mengklaim asuransi dan menggunakan hasil klaim tersebut untuk melunasi hutang debitur, sedangkan jika objek jaminan fidusia belum diasuransikan pada saat kemusnahan tersebut maka pihak kreditur meminta debitur untuk mengganti benda yang musnah tersebut dengan benda lain yang dimiliki debitur saat ini ataupun yang akan datang, dan benda pengganti tersebut harus memiliki nilai jual yang sama dengan kredit atau pinjaman yang telah dikeluarkan oleh pihak kreditur. Dengan kata lain pihak debitur tetap bertanggung jawab untuk melunasi hutangnya walaupun objek jaminan yang telah dijaminkan mengalami kemusnahan. Hal ini sejalan denga (Meilaputri, Suryani, \& Seputra, 2019;Wijaya, 2020) mengatakan bahwa hendaknya lembaga pembiayaan konsumen mendaftarkan akta pembebanan jaminan tersebut pada Kantor Fidusia agar mempunyai kepastian hukum sebagai kreditur preferen. Selain itu, dapat menggunakan haknya untuk menjual lelang Jaminan Fidusia ketika debitur wanprestasi.

\section{SIMPULAN DAN SARAN}

\section{Simpulan}

Berdasarkan hasil analisis dan deskripsi di atas, maka dapat disimpulkan bahwa kedudukan hukum perjanjian kredit jika objek jaminan fidusia musnah baik dalam hal benda yang menjadi objek telah diasuransikan maupun belum diasuransikan oleh pemilik benda. Perjanjian kreditnya tetap ada dan debitur tetap bertanggung jawab atas pelunasan atas utangnya. Dengan situasi tersebut maka pihak kreditur akan berubah menjadi kreditur konkuren. Selanjutnya, dalam menyelesaikan sengketa musnahnya objek jaminan fidusia terdapat dua cara yaitu, jika benda yang dijadikan objek jaminan fidusia oleh debitur dalam suatu perjanjian kredit telah diasuransikan maka pihak kreditur bisa mengklaim asuransi atas benda yang dijaminkan tersebut. Sedangkan jika benda yang dijadikan jaminan belum diasuransikan dalam hal ini kreditur telah mengeluarkan kredit dan sedang mengurus asuransi benda tersebut, terjadi peristiwa yang tidak diinginkan oleh pihak debitur maupun kreditur yaitu musnahnya benda yang dijadikan jaminan. Maka debitur tetap harus ertanggung jawab dengan mengganti benda yang dijaminkan dengan benda baru yang dimiliki pihak debitur dan nilai jualnya sama dengan kredit yang telah dikeluarkan oleh pihak kreditur.

\section{Saran}

Adapun rekomendasi berdasarkan hasil analisis di atas yaitu diperlukan penjelasan mengenai setiap pasal yang tercantum dalam Undang-undang Nomor 42 Tahun 1999 tentang Jaminan Fidusia agar tidak terjadi multitafsir terhadap pasal-pasal yang belum jelas. Dan mempertegas ketentuan kedudukan perjanjian kredit jika terjadi suatu peristiwa yang terjadi diluar kehendak debitur dan kreditur. Agar para pihak yang terlibat terlindungi kedudukannya. Kemudian, kejelasan prosedur pemberian kredit oleh BPR Bumi Prima Dana dan Koperasi Bina Karya Utama menyangkut benda yang dijadikan objek jaminan. Untuk mengantisipasi keluarnya kredit tanpa mengetahui kejelasan status benda yang dijaminkan telah diasuransikan atau sedang dalam proses untuk diasuransikan.

\section{DAFTAR PUSTAKA}

Fuady, Munari. (1996). Hukum Perkreditan Kontemporer. Bandung: Citra Aditya Bhakti.

Fuady, Munir. (2000). Jaminan Fidusia. Bandung: Citra Aditya Bakti.

Hariyani, I. (2016). Penjaminan Hak Cipta Melalui Skema Gadai dan Fidusia. Jurnal HukumIUS QUIA IUSTUM, 23(2), 294-319. https//doi.org/10.20885/iustum.vol23. iss2.art7

Jayanti, A. A. A. S. W. (2018). Motorcycle as a Fidusia Guarantee Object in Financing Companies in PT Adira Cabang Denpasar, 3(2), 122-129. https://doi.org/10.22225/jn.3.2.747.122-129

K, C. T. S. (2017). Aspek Hukum Benda Tidak Bergerak Sebagai Obyek Jaminan Fidusia. Jurnal Notariil, 1(2), 13-22. https://doi.org/10.22225/jn.2.1.150.13-22

Meilaputri, I. G. A. D., Suryani, L. P., \& Seputra, P. G. (2019). Kekuatan Hukum Sertifikat Jaminan Fidusia yang Didaftarkan Setelah Terjadinya Wanprestasi. Kertha Wicaksana: Sarana Komunikasi Dosen Dan Mahasiswa, 13(2), 69-72. Retrieved from https://ejournal.warmadewa.ac.id/index.php/kertawicaksana/article/view/1211

Putriyanti, E. D. (2017). Legal Status of Credit Bank Guarantee in Indonesia's Legal Guarantee. Sriwijaya Law Review, 1(2), 128-141. https://doi.org/10.28946/s lrev.vol1.iss2.38.pp 128-141

Satrio. (2005). Hukum Jaminan Hak Jaminan Kebendaan Fidusia. Bandung: Citra Aditya Bakti.

Tumbuan, F. B. . (2000). Himpunan Kajian Mengenai Beberapa Produk Legislasi dan Masalah Hukum 
Di Bidang Hukum Perdata. Jakarta: Gramedia Pustaka Utama.

Tumbuan, F. G. (2000). Peraturan Pelaksanaan UU Jaminan Fidusia. Jakarta: BP Cipta Jaya.

Wijaya, H. T. (2020). Akibat Hukum Atas Penyitaan Obyek Jaminan Fidusia Yang Tidak Didaftarkan.

Jurnal Hukum Bisnis Bonum Commune, 3(1), 39-53. https://doi.org/10.30996/jhbbc.v3i1.3039

Yasir, M. (2016). Aspek Hukum Jaminan Fidusia (Legal Aspect of Fiduciary Guaranty). SALAM:

Jurnal Sosial Dan Budaya Syar-I, 3(1), 75-92. https //doi.org/10.15408/sjs bs.v3i1.3307 